\title{
Aerosol Spray Dosage Form
}

National Cancer Institute

\section{Source}

National Cancer Institute. Aerosol Spray Dosage Form. NCI Thesaurus. Code C42889.

A spray that is packaged under pressure and released upon activation of an appropriate valve system. 